\title{
PEMBUATAN SAFETY DEVICE COOLING DOWN AUTOMATIC PADA UNIT HEAVY EQUIPMENT DOZER D3K CATERPILLAR BERBASIS MICROCONTROLLER
}

\author{
Abdul Halim ${ }^{1}{ }^{\square}$, Mangkona $^{1}$, Muh. Taufik ${ }^{1}$, Andi Saputra ${ }^{1}$

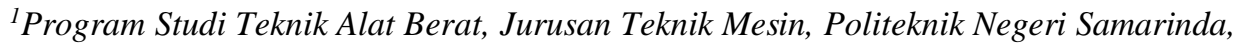 \\ Jl. Dr. Ciptomangunkusumo, Kampus Gunung Lipan, Samarinda, 75131 \\ $\square_{\text {e-mail: halim72@polnes.ac.id }}$
}

\begin{abstract}
The occurrence of problems regarding operating procedures that are not suitable for heavy equipment in the field is one of the causes of component life which is not maximally achieved. Therefore it is necessary to have an innovation to make it easier to monitor and operate heavy equipment, especially when there is a shift in work shift for heavy equipment operators. Operator experience in several mining activities, many operators shut down the engine suddenly so that the impact on the engine can cause over heating which results in excessive wear and will have an impact on engine performance. And therefore the purpose of making a microcontroller-based cooling down safety device is a tool that functions to turn off the engine when the engine is low idle with time settings according to the standard operating procedure of each machine. For machines that have been operated under load, the engine must be low idle / cooling down for a while, so that the heat on the engine surface is cool enough, so that hot components can be properly lubricated. By making a cooling down engine safety device, it is hoped that it can assist in the monitoring and operation of heavy equipment. From the results of field testing, the relay that controls the unit's electricity functions properly and the cooling down safety device has a precise timing.
\end{abstract}

Keyword : Cooling Down, Microcontroller, Heavy Equipment, Safety Device

\begin{abstract}
Abstrak
Terjadinya problem mengenai prosedur pengoperasian yang tidak sesuai pada heavy equipment di lapangan, merupakan salah satu penyebab usia komponen tidak tercapai secara maksimal. Maka dari itu perlu adanya sebuah inovasi untuk lebih memudahkan dalam monitoring dan pengoperasian heavy equipment utamanya pada saat terjadi pergantian shift kerja operator heavy equipment. Pengalaman operator dibeberapa kegiatan mining, banyak operator mematikan engine secara tiba-tiba sehingga dampaknya pada engine bisa menimbulkan over heating yang mengakibatkan terjadinya keausan yang berlebihan dan akan berdampak pada performance engine tersebut. Dan karenanya tujuan pembuatan safety device cooling down yang berbasis microcontroller merupakan alat yang berfungsi untuk mematikan engine saat engine low idle dengan settingan waktu sesuai standar operasional procedure yang dimiliki masing-masing machine. Machine yang telah dioperasikan under load, maka engine harus dilakukan low idle/ cooling down untuk beberapa saat, agar temperature panas pada permukaan engine turun, sehingga komponen yang panas dapat terlumasi dengan baik. Dengan pembuatan safety device engine cooling down diharapkan dapat membantu dalam proses monitoring dan pengoperasian heavy equipment. Dari hasil pengujian lapangan relay yang mengontrol kelistrikan unit berfungsi dengan baik dan safety device cooling down memiliki waktu 5 menit untuk engine shutdown.
\end{abstract}

Kata Kunci : Cooling Down, Microcontroller, Heavy Equipment, Safety Device

Pendahuluan

Aktifitas kegiatan unit alat berat sudah sangat meluas diberbagai sektor proyek. Populasi jenis produk alat berat yang di produksi sesuai aplikasi di lapangan, dimana produk alat berat sangat banyak diaplikasikan seperti pada mining, marine, earth moving, generator set, agricultures, oil \& gas. Penggunaan alat berat yang semakin banyak tersebut tentunya berdampak secara langsung terhadap lingkungan seperti contoh polusi 
udara, sehingga tuntutan customer tentang performance alat berat juga menjadi catatan penting bagi produsen alat berat. Dengan berkembangnya teknologi yang semakin canggih, sehingga dalam mengatasi dampak lingkungan atas polusi tersebut, banyak alat berat yang mengalami perubahan sejak awal dibuat seperti contoh engine mechanical berubah menjadi engine electronic, penambahan komponen turbocharger, aftercooler perubahan fuel system, dan lain - lain. Begitu pula dengan maintenance dan standar pengoperasiant.

Terkait dengan standar pengoperasian khususnya dalam meng-offkan engine atau mesin unit heavy equipment, mempunyai Standard Operation Procedure (SOP) masing-masing berdasarkan pada jenis dari product heavy equipment. Tujuan dari SOP atau teknik untuk shutdown engine ini untuk menjaga performance engine sehingga bisa digunakan dalam waktu yang lebih lama dengan kinerja yang efektif dan efisien. Apabila shutdown engine secara mendadak sebelum engine dingin, umur mesin tidak awet karena pada saat mesin dilakukan shutdown secara mendadak maka panas yang terjadi belum sempat terbuang pada posisi mesin shutdown, dan sistem pendingin akan berhenti bekerja, maka dari itu sangat diperlukan jeda waktu antara penghentian pemakaian dengan shutdown engine sehingga panas yang dihasilkan oleh mesin dapat diturunkan sebelum engine shutdown.

Dengan adanya improvisasi yang dilakukan membuat performance machine/engine semakin bandel dan efisien, sehingga lebih memudahkan para pengguna dalam melakukan pekerjaan, perawatan dan perbaikan. Disisi lain pengoprasian machine yang tidak benar dapat memperpendek usia komponen engine, seperti contoh pada unit dozer D3K, jika mematikan engine dengan segera setelah mesin di operasikan dalam kondisi under load maka dapat menyebabkan overheating dan mempercepat keausan pada komponen engine, maka solusinya adalah setelah mesin stop dan di parkir, jadi sebelum dilakukan engine shutdown biarkan engine running atau idle selama 5 menit sebelum dimatikan. Melakukan running engine selama 5 menit membuat permukaan temperature engine turun secara perlahan sebagaimana standard procedure operational dari literature product line [1].

Dari permasalahan diatas, maka perlu dikembangkan suatu system hardware untuk menjaga problem tersebut. Sistem ini dapat bekerja secara otomatis dengan menggunakan relay kemudian secara otomatis data diproses di dalam mikrokontroller dan juga terdapat fiturfitur pada alat ini yaitu mampu mendeteksi dimana unit terakhir dimatikan serta dapat melacak unit via android serta shutdown engine dari jarak jauh. Penggunaan mikrokontroller dikarenakan saat ini banyak digunakan untuk kontrol sistem dan otomasi, serta kemudahannya dalam pemograman [2].

Pada banyak penelitian yang menggunakan microcontroller, penelitian ini mencoba pengembangankan dengan problem yang berbeda dan inovasi yang berbeda yang tentunya di dasarkan pada kajian lapangan terhadap pengoperasian unit alat berat khususnya untuk safety device cooling down dalam meng-offkan unit alat berat. Penelitian yang dilakukan [3] mencoba membuat alat multi timer yang dapat bekerja dengan baik dengan beberapa percobaan menggunakan lima beban sekaligus. Terbukti bahwa microcontroller dapat mengontrol rangkaian switching berdasarkan input waktu dari RTC sehingga ON/OFF beban dapat dikontrol dengan waktu yang tepat. Pemanfaatkan starting system dengan pembuatan biometric starting system 
adalah sistem dapat berkomunikasi dengan model fingerprint berupa "oncontact", "starter motor", "off-contact", dan "error" dan alat dapat bekerja dengan baik [4]. Begitupula penelitian yang dilakukan [5] dimana melakukan rancang bangun sebuah safety device pada engine oil level dengan starting sistem yang di nonaktifkan ketika level oli mesin mencapai batas yang ditentukan.

Berdasarkan dari literatur penelitian sebelumnya di atas, menunjukkan adanya penggunaan metode yang sama namun obyek dan sistem pengontrolan yang berbeda dengan apa akan dikembangkan dan dibuat pada penelitian ini. Adapaun problem statemennya adalah : bagaimana cara kerja safety device cooling down otomatis ?; dan bagaimana cara mengatur timer pada unit agar dapat shutdown secara otomatis dengan mengacu pada spesifikasi unit?.

\section{Rangkain Kelistrikan Starting System D3K Caterpillar}

Penulis mengacu pada skematik kelistrikan Dozer D3K Caterpillar dengan media number [6], sebagai literatur untuk mengidentifikasi komponen serta skematik kelistrikan pada starting system, yang kemudian digunakan sebagai referensi pemasangan alat yang dibuat. Komponen pada sistem kelistrikan tersebut antara lain (1) Key Start Switch, (2) Main Relay, (3) Disconnect Switch, (4) Battery, (5) Start Relay, (6) Motor Starter, seperti pada Gambar 1.

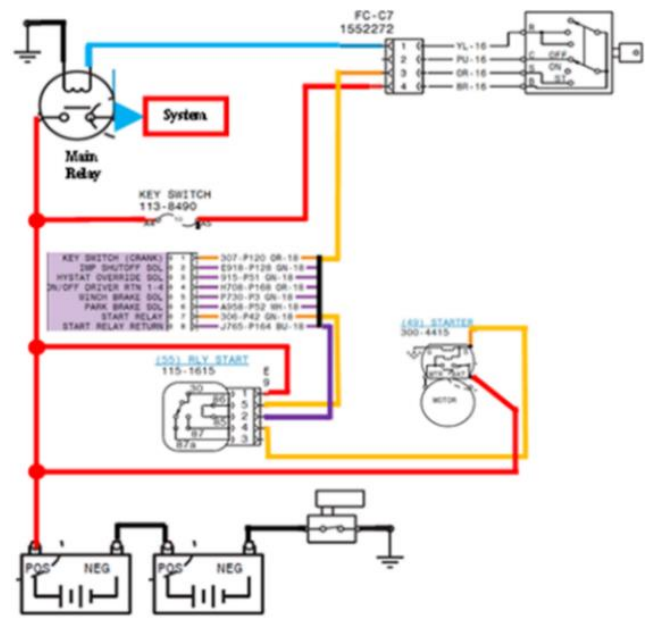

Gambar 1. Rangkain Kelistrikan StartingSystem D3K Caterpillar

Ketika disconnect switch pada posisi ON maka ground pada system akan terhubung dengan ground body dan negative battery, sehingga ketika dialiri listrik maka komponen bisa bekerja. Pada kondisi ini arus listrik dari positif battery sudah stand by pada motor starter, start relay, main relay, dan key switch. Ketika key switch pada posisi OFF maka arus dari battery tidak akan mengalir ke system karena masih dalam keadaan normally open. Ketika key switch pada posisi ON maka battery akan mengalirkan arus dari main relay menuju semua system, sehingga beberapa system kelistrikan sudah ON. Pada kondisi ini motor starter belum running. Ketika start relay aktif maka akan mengalirkan arus besar dari battery menuju motor starter sehingga motor starter bisa crank, dan memutar engine, maka engine pun bisa running.

Microcontroller ATmega Arduino Microcontroller merupakan sebuah chip yang bagian dalammnya terdiri dari mikroprosesor yang telah dipadukan I/O dan Random Access Memory (RAM)/ Read Only Memory (ROM)" [7]. Microcontroller merupakan intergrated circuit (IC) yang bekerja untuk aplikasi kontrol. Program menginstruksikan microcontroller untuk melakukan hubungan yang lebih jauh dari aksi-aksi 
sederhana untuk melakukan tugas yang lebih kompoleks berdasarkan kemauan programmer [8].

Penelitian ini menggunakan Arduino nano yang merupakan salah satu jenis dari produk board microcontroller keluaran Arduino. Arduino nano merupakan board keluaran terkecil dengan ukuran $4.5 \mathrm{~mm} \times 18 \mathrm{~mm}$, yang menggunakan micro controller ATmega 328 [9]. Arduino nano mempunyai fungsi yang hampir sama dengan arduino duemilanove, namun dengan paket berbeda. Adapun perbedaannya adalah, arduino nano tidak disertai port DC berjenis Barrel Jack, dan port USB MiniB yang dihubungkan ke komputer. Arduino didesain dan diproduksi oleh perusahaan Gravitech [10].

Arduino nano mempunyai 14 jumlah pin yang dapat digunakan untuk input dan output dan memiliki beberapa fungsi pin mode, digital write, digital read. Pin arduino nano bekerja pada tegangan $5 \mathrm{~V}$ dengan Arus $20 \mathrm{~mA}$ serta memiliki tahanan pull - up 20 - 50k ohm. Arduino nano mempunyai fasilitas untuk berkomunikasi dengan personal computer, Arduino atmega 328 memiliki fasilitas serial komunikasi UART TTL (5V), yang tersedia pada pin digital 0 (RX) dan 1 (TX) [13]. Untuk konstruksi fisik dari komponen sistem arduino nano dapat dilihat pada Gambar 2.

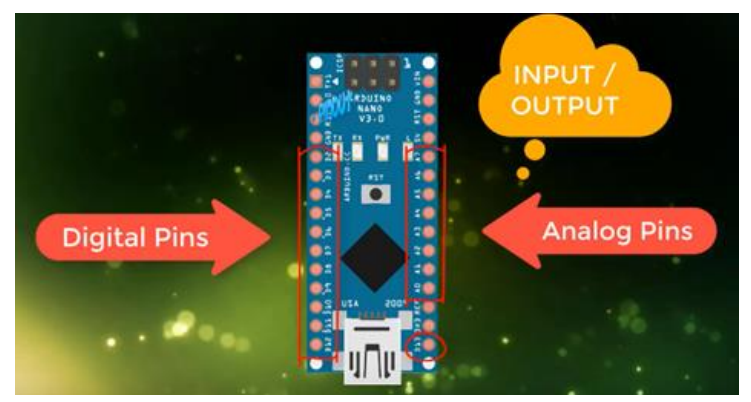

Gambar 2. Komponen Arduino Nano

\section{Metode Penelitian}

Perancangan Schematic Diagram Sistem Safety Device Cooling Down Otomatic Supaya alat yang dibuat dapat mengatur waktu engine idle dan mematikan engine maka diperlukan desain skema rangkaian kelistrikan unit D3K terutama pada rangkaian starting system-nya. Karena alat yang dibuat harus memutus kelistrikan melalui starting system atau rangkaian sebelum main relay. Dengan memutus kelistrikan dari main relay maka seluruh kelistrikan unit akan mati. Proses memutuskan listrik dikontrol oleh micro controller melalui module relay.

\section{Diagram Alir Kerja Automatic Engine Cooling Down}

Cara kerja automatic engine cooling down dijelaskan dalam diagram alir pada Gambar 3. sebagai berikut:

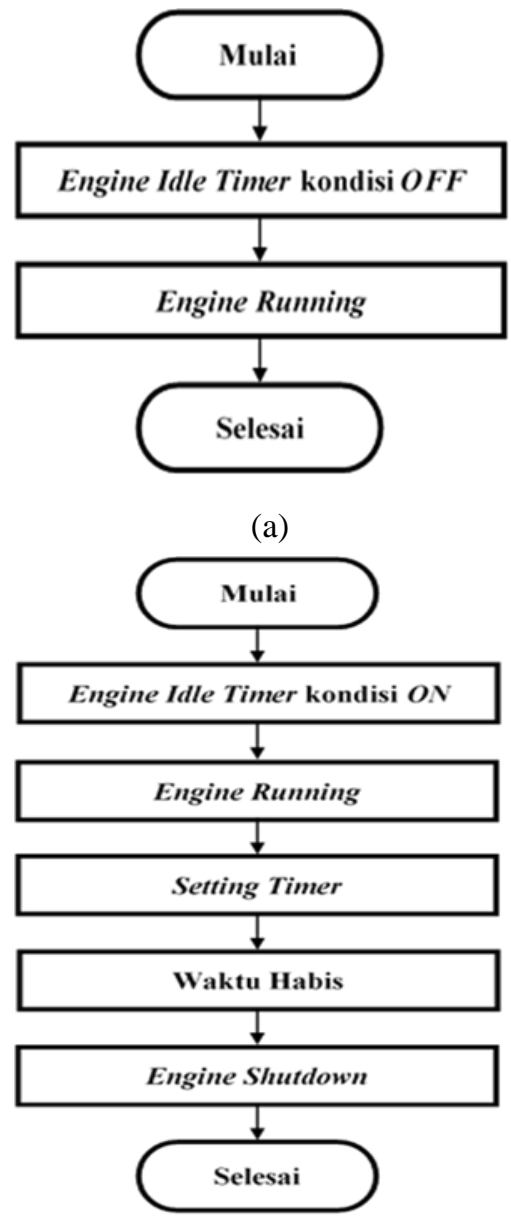

(b) 


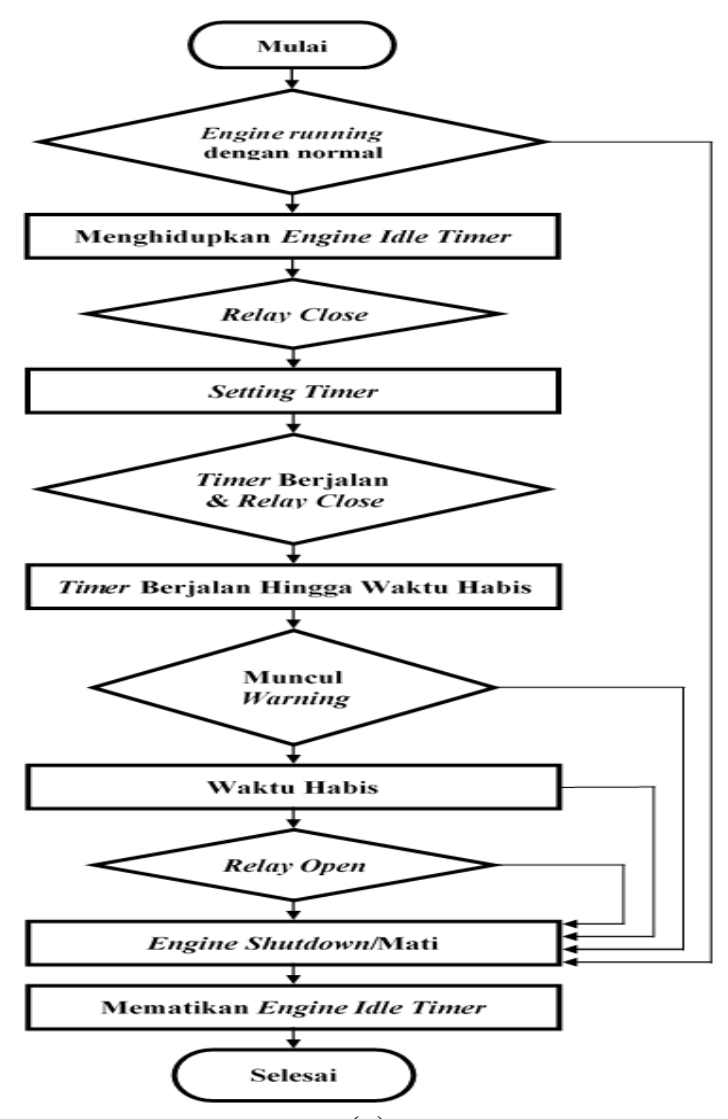

(c)

Gambar 3. (a) Diagram alir menghidupkan machine tanpa automatic engine shutdown; (b) Diagram Alir Menghidupkan Engine Dengan Automatic engine shutdown; (c) Diagram Alir Mengoperasikan Dan Mematikan Engine.

\section{Hasil dan Pembahasan}

\section{Implementasi sistem kelistrikan Safety Device Engine Cooling Down Dozer D3K}

Rancangan sebagaimana pada sistem schematic eletrict pengkabelan (Gambar 4) dan implementasi sistem (Gambar 5). Pada sistem terdapat 8 buah komponen elektronika yang dirangkai menjadi satu group alat. Setiap komponen mempunyai fungsi dan cara kerja masing-masing. Switch sebagai inputan dan arduino terhubung pada port arduino. Arduino sebagai microcontroller untuk memproses data sinyal input dari sensor. Mikrokontroller arduino cukup tangguh untuk diprogram dan dikembangkan, seperti pada penelitian yang dilakukan [11], [12] dengan memadukan sistem fuzzy logic terintegrasi untuk mikrokontroller arduino. Relay yang terhubung pada port arduino sebagai output yang berfungsi memutus dan menghubungkan jalur starting terminal $\mathrm{C}$ starting switch dengan motor stater. Board sebagai tempat menghubungkan komponen satu sama lain. Buzzer berfungsi sebagai output yang terhubung pada port Arduino yang akan mengeluarkan suara ketika waktu tercapai . Sistem ini dapat menampilkan karakter text pada LCD seperti dalam [13] yang berfungsi sebagai output dari arduino. Sementara stepdown berfungsi menurunkan tegangan 24 volt menjadi 8 volt.

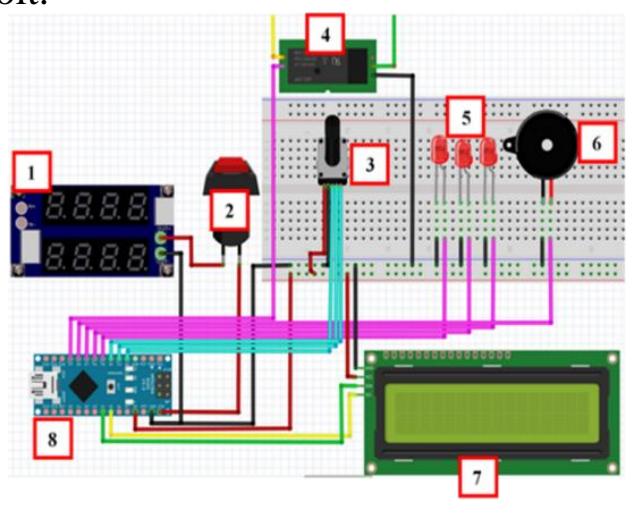

Gambar 4. Skematik automatic electrical (system pengkabelan) safety device cooling down

Gambar 4 menunjukkan rangkaian dari komponen yang digunakan pada Safety device cooling down yang terdiri dari (1) Voltage Regulator, (2) Power Switch, (3) Rotary Encoder, (4) Relay, (5) LED, (6) Buzzer, (7) LCD 16x2, (8) Arduino Nano.

\section{Memasang Safety Device Cooling Down}

Proses pemasangan Safety device cooling down ke unit cukup mudah, gunakan pin connector yang sudah dimodifikasi dengan aman (gambar dibawah) untuk menghubungkan power source ke Safety device cooling down dan menghubungkan sirkuit key start switch 
ke modul relay Safety device cooling down.

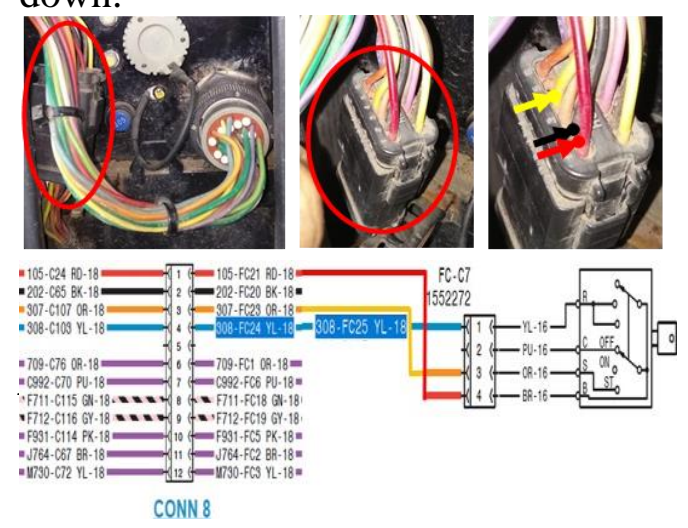

Gambar 5. Lokasi connector no 8 \& pin connector digunakan pada unit dozer D3K Caterpillar

Pastikan connector dan pin yang digunakan sesuai dengan literature. Hatihati saat melepas pin dengan kabel warna merah dan hitam (kabel power source). Pastika key start switch dalam kondisi OFF, jangan sampai menyatukan keduanya karena bisa menyebabakan short dan menyebabkan fuse key start switch putus. Kabel merah pin 1 dan kabel hitam poin 2 sebagai power source untuk safety device cooling down sedangkan kabel kuning pin 3 adalah kabel yang akan dikontrol oleh micro controller. Setelah extension di pasangkan pada unit dan safety device cooling down, selanjutnya me-running safety device cooling down.

\section{Menghidupkan Safety Device Cooling Down}

Safety device cooling down dapat dihidupkan dan dimatikan dengan mudah, dibuat dan dipasangkan tanpa mengganggu system dari unit ketika sedang tidak digunakan. Proses menghidupkannya sangat mudah cukup dengan menekan tombol power dan jika ingin mematiakan engine cukup menyetel berapa lama waktu yang dibutuhkan dengan tombol rotary encoder Permeability media pasir.

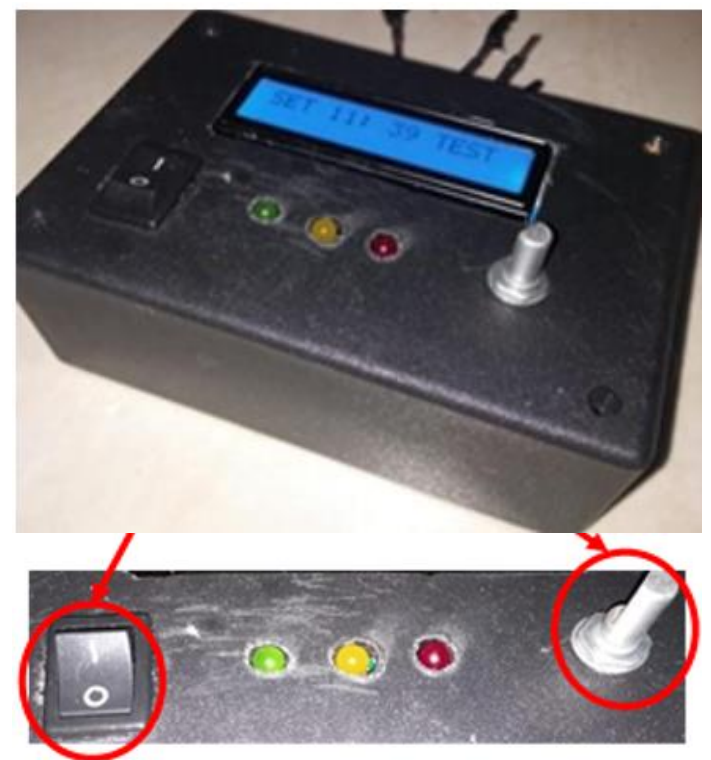

Gambar 6. Switch Power \& Rotary Encoder

Pada saat switch power diaktifkan maka program yang telah di-upload ke board arduino akan dieksekusi oleh micro controller. Selanjutnya untuk dapat mematikan engine maka harus menyetting waktu berapa menit dan detik dengan menggunakan rotary encoder. Ketika waktu telah di-setting selanjutnya tekan rotary encoder untuk mulai menjalankan timer yang telah di-setting. Selanjutnya timer akan bekerja sesuai dengan hasil settingan yang diberikan. Ketika waktu hampir selesai microcontroller dapat mengaktifkan buzzer sebagai peringatan. Ketika timer sudah habis maka micro controller akan mengaktifkan relay. Saat relay aktif $(\mathrm{ON})$ maka arus listrik dari key start switch ke main relay akan diputus sehingga engine akan mati.

\section{Pengujian Setiap Komponen}

Ketika alat sudah selesai dirakit harus dilakukan pengujian setiap komponen dalam keadaan terpasang untuk memastikan komponen telah terpasang dengan benar. Berikut kondisi komponen yang telah terpasang, hasil pengujian disajikan dalam bentuk tabel 1 berikut : 
Tabel 1. Hasil Pengujian Komponen

\begin{tabular}{cllc}
\hline No & Komponen & $\begin{array}{l}\text { Jenis } \\
\text { Pengujian }\end{array}$ & Ket \\
\hline 1 & $\begin{array}{l}\text { Arduino } \\
\text { Nano }\end{array}$ & $\begin{array}{l}\text { Reading } \\
\text { Test }\end{array}$ & Baik \\
\hline 2 & $\begin{array}{l}\text { Relay } \\
\text { Module }\end{array}$ & $\begin{array}{l}\text { Continuty } \\
\text { Test }\end{array}$ & Baik \\
\hline 3 & LCD & $\begin{array}{l}\text { Writing } \\
\text { Test }\end{array}$ & Baik \\
\hline 4 & $\begin{array}{l}\text { Power } \\
\text { Switch }\end{array}$ & $\begin{array}{l}\text { Continuty } \\
\text { Test }\end{array}$ & Baik \\
\hline 5 & $\begin{array}{l}\text { Rotary } \\
\text { Encoder }\end{array}$ & $\begin{array}{l}\text { Continuty } \\
\text { Test }\end{array}$ & Baik \\
\hline 6 & Buzzer & $\begin{array}{l}\text { Active } \\
\text { Test }\end{array}$ & Baik \\
\hline
\end{tabular}

\section{Pengukuran Ketepatan Waktu Safety Device Cooling Down}

Untuk mengukur ketepatan waktu automatic engine shutdown dilakukan dengan cara membandingkannya dengan stopwatch ketika timer pada automatic engine shutdown dimulai. Pengukuran dilakukan dengan rentang waktu 1 menit dan 5 menit dengan 10 kali percobaan dan hasilnya dapat dilihat pada tabel dibawah ini:

Tabel 2. Hasil Pengukuran Ketepatan Waktu

\begin{tabular}{cccc}
\hline Percobaan & $\begin{array}{c}\text { Safety } \\
\text { Device } \\
\text { Cooling } \\
\text { Down }\end{array}$ & $\begin{array}{c}\text { Timer } \\
\text { Smart- } \\
\text { phone }\end{array}$ & $\begin{array}{c}\text { Selisih } \\
\text { Waktu }\end{array}$ \\
\hline 1 & 1 menit & 1 menit & 0 \\
\hline 2 & 1 menit & 1 menit & 0 \\
\hline 3 & 1 menit & 1 menit & 0 \\
\hline 4 & 1 menit & 1 menit & 0 \\
\hline 5 & 1 menit & 1 menit & 0 \\
\hline 6 & 5 menit & 5 menit & 0 \\
\hline 7 & 5 menit & 5 menit & 0 \\
\hline 8 & 5 menit & 5 menit & 0 \\
\hline 9 & 5 menit & 5 menit & 0 \\
\hline 10 & 5 menit & 5 menit & 0 \\
\hline
\end{tabular}

\section{Grafik Hasil Pengukuran Ketepatan} Waktu Automatic Engine Shutdown

Dari hasil pengukuran yang telah dilakukan maka dibuatlah dalam bentuk grafik perbandingan pengukuran ketepatan waktu antara Safety device cooling down dengan stopwatch. Berikut garfik perbandingannya:

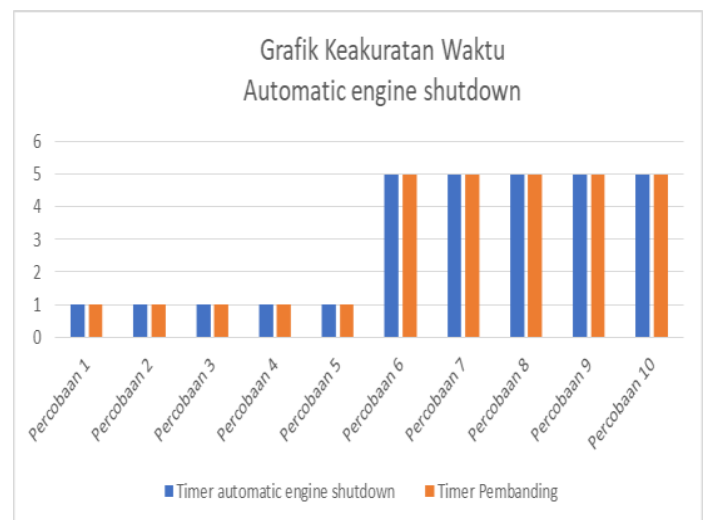

Gambar 7. Grafik perbandingan ketepatan waktu

Dari grafik Gambar 7 dapat disimpulkan bahwa timer pada safety device cooling down sudah presisi, karena dari setiap percobaan dengan timer pembanding menunjukkan hasil yang sama.

\section{Grafik Voltage Saat Engine Running}

Gambar 8 adalah grafik hasil pengukuran voltage drop di line regulator regulator yang terhubung ke main relay, key switch dan moto starter ketika engine running dengan dipasangkan safety device cooling down tidak mempengaruhi system kerja engine

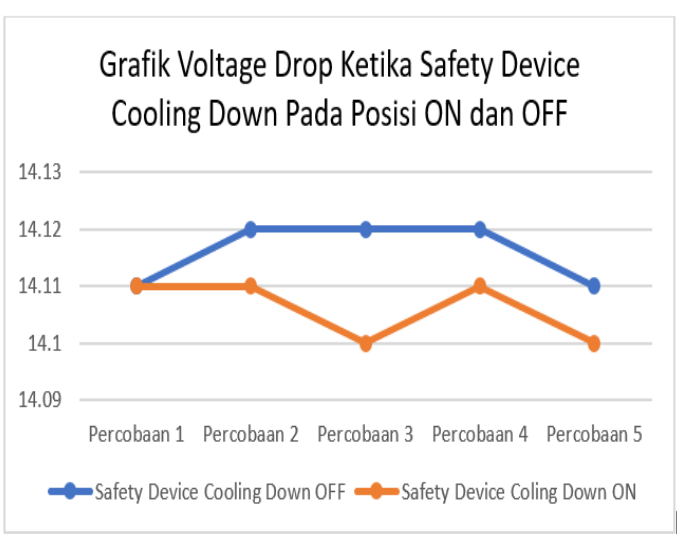

Gambar 8. Grafik Pengukuran Voltage Saat Engine Running 


\section{Grafik Current Saat Engine Running}

Gambar 9 adalah grafik hasil pengukuran current line regulator yang terhubung ke main relay, key switch dan moto starter ketika engine running dengan dipasangkan safety device cooling down:

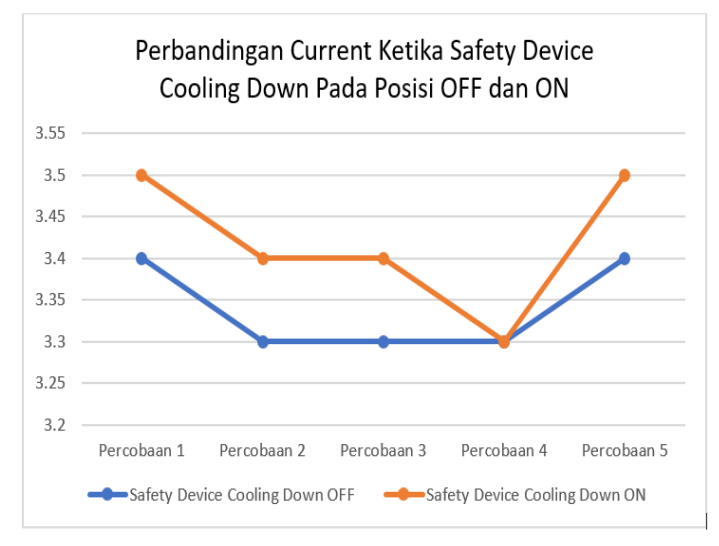

Gambar 9. Grafik Pengukuran Current Saat Engine Running

Dari grafik diatas dapat disimpulkan bahwa pemasangan safety device cooling down tidak mempengaruhi performa engine D3K karena perbedaannya current hanya maksimal 0.1 Ampere dalam kondisi low idle.

\section{Kesimpulan}

Setelah melakukan perakitan automatic safety device cooling down dan melakukan pengujian ke unit maka dapat disimpulkan bahwa desain alat tersebut dapat beroperasi dengan baik, yaitu dapat mematikan engine sesuai dengan waktu yang telah diatur. Adapun beberapa kesimpulan lainnya adalah sebagai berikut:

1. Relay yang mengontrol kelistrikan unit dapat berfungsi dengan baik melalui tahapan pengujian yang telah dilakukan sehingga dapat dipastikan automatic safety device engine cooling down untuk melakukan shutdown dapat beroperasi dengan aman.
2. Automatic safety device engine cooling down memiliki waktu yang sudah tepat berdasarkan tahapan yang telah dilakukan sehingga tidak akan menyebabkan overtime ketika me-running engine.

3. Engine idle timer memiliki waktu yang sudah presisi.

4. Pemasangan engine idle timer ke unit cukup mudah, karena hanya menggunakan tiga kabel output.

\section{Ucapan Terima kasih}

Ucapan terima kasih kepada Program Studi Teknik Alat Berat Politeknik Negeri Samarinda atas pemanfaatan workshop sebagai pusat penelitian dan pengujian.

\section{Daftar Pustaka}

[1] [SEBU82B-04], "Media Number Operating \& Maintenance Manual D3K, D4K \& D5K Track Type Tractor [Machine]," Catsch 2009 [Online]. Tersedia : http:// www.catsch.info [Diakses 20 Januari 2020].

[2] T. Budioko, "Belajar dengan mudah dan cepat pemrograman Bahasa $C$ dengan SDCC (Small Device C Compiler) Pada Mikrokontroler AT 89X051/At 89c51/52 Teori, Simulasi dan Aplikasi," Yogyakarta: Gava Media, 2005

[3] T. Risard Lowongan, P. Rahardjo, and Y. Divayana, "Detektor LPG Menggunakan Sensor MQ2 Berbasis Mikrokontroler ATMega 328," Jurnal Ilmiah SPEKTRUM, vol. 2, no. 4, pp. 53-57, 2015

[4] A. Halim, Mangkona, and R. Z. Zuhri, "Rancang Bangun Biometric Starting System Berbasis Microcontroller ATmega 328P Untuk Operator Alat Berat Dozer D3K Caterpillar." JTT (Jurnal Teknologi Terpadu), vol. 8, no. 1, pp. 56-63, 2020. 
[5] R. Randis, S. Akbar, R. Darmawan, "Implementasi Sistem Safety Device Engine Oil Level PC 200-7 Berbasis Arduino," Media Mesin: Majalah Teknik Mesin, vol. 19, no. 2, pp. 90-98, 2019

[6] KENR5969-04, "Schematic Electric Dozer D3K Caterpillar (Media Number KENR5711-04)," 2017.

[7] J. Prayudha, D. Nofriansyah, and M. Ikhsan, "Otomatisasi Pendeteksi Jarak Aman Dan Intensitas Cahaya Dalam Menonton Televisi Dengan Metode Perbandingan Diagonal Layar Berbasis Mikrokontroler Atmega 8535," Jurnal SAINTIKOM, vol. 13, no. 3, pp.171182, Sep. 2014

[8] H.L. Sadewa, H. Sujaini, and R.D Nyoto, "Implementasi Mikrokontroler Pada Sistem Kontrol Peralatan Listrik dan Monitoring Rumah Berbasis Website," JEPIN (Jurnal Edukasi dan Penelitian Informatika), vol. 1, no. 2, pp. 99-105, 2015.

[9] Zulkarnain, Andriana, and A. Rosyada, "Pembuatan Prototipe Alat Pemberi Pakan Kucing Otomatis Berbasis Arduino Nano Dan Terintegrasi Dengan Handphone Via SMS," Jurnal TIARSIE, vo.16, no. 2, pp. 59-64, 2019

[10] Pinem, S. Malinda, "Sistem Pengukuran Kadar Aseton Dengan Nafas Berbasis Arduino Nano Dengan Tampilan Android," Fakultas Teknik, Jurusan Teknik Elektro, Universitas Sumatera Utara, Medan, 2016.

[11] F. Chabni, R. Taleb, A. Benbouali, and M. A. Bouthiba, "The Application of Fuzzy Control in Water Tank Level Using Arduino," Int. J. Adv. Comput. Sci. Appl., vol. 7, no. 4, pp. 261-265, 2016.

[12] Indriastuti, M. Theresia, S. Arifin, N. Fadhilah, and T. Aprilianto,
"Rancang Bangun Sistem Keamanan Sepeda Motor Menggunakan Arduino Nano Dan Android Via Bluetooth," Jurnal Ilmiah Teknologi Informasi Asia, vo. 14 , no. 1 , pp. 19-30, 2020

[13] A. Amin, "Monitoring Water Level Control Berbasis Arduino Uno Menggunakan LCD LM016L," Jurnal EEICT, vol. 1, no. 2, pp. 41-52, 2018 